\title{
Development of a Real-Time Polymerase Chain Reaction Assay for Quantifying Verticillium albo-atrum DNA in Resistant and Susceptible Alfalfa
}

\author{
R. C. Larsen, G. J. Vandemark, T. J. Hughes, and C. R. Grau
}

First and second authors: USDA-ARS, Vegetable and Forage Crop Research Unit, 24106 North Bunn Road, Prosser, WA 99350; third and fourth authors: Department of Plant Pathology, 1630 Linden Drive, University of Wisconsin, Madison 53706. Accepted for publication 21 July 2007.

\begin{abstract}
Larsen, R. C., Vandemark, G. J., Hughes, T. J., and Grau, C. R. 2006. Development of a real-time polymerase chain reaction assay for quantifying Verticillium albo-atrum DNA in resistant and susceptible alfalfa. Phytopathology 97:1519-1525.

A precise real-time polymerase chain reaction (PCR) assay was developed for quantifying Verticillium albo-atrum DNA. The assay was used in a repeated experiment to examine the relationship between the quantity of pathogen DNA detected in infected leaves and shoots and the severity of Verticillium wilt symptoms in several alfalfa cultivars expressing a range of disease symptoms. Plants were visually inspected for symptoms and rated using a disease severity index ranging from 1 to 5 , and the quantity of pathogen DNA present in leaves and stems was determined with realtime PCR. No significant differences in pathogen DNA quantity or dis-

ease severity index were observed for experiments or for cultivar-experiment interactions. Significant differences were observed between cultivars for the quantity of pathogen DNA detected with real-time PCR and also for disease severity index ratings. In both experiments, the highly resistant check cultivar Oneida VR had significantly less pathogen DNA, and significantly lower disease severity index ratings than the resistant cultivar Samauri, the moderately resistant cultivar Vernema, and the susceptible check cultivar Saranac. In both experiments, the Spearman rank correlation between the amount of $V$. albo-atrum DNA detected in leaves and stems with real-time PCR and disease severity index ratings based on visual examination of symptoms was positive $(>0.52)$ and significant $(P<0.0001)$. These results suggest that resistance to Verticillium wilt in alfalfa is characterized by a reduced colonization of resistant genotypes by the fungus.
\end{abstract}

Verticillium wilt is a destructive soilborne fungal disease that affects many important agricultural and horticultural crops worldwide. The most common species is Verticillium dahliae Kleb and has a broad host range, while the host range of $V$. alboatrum Reinke and Berth is limited primarily to alfalfa, hops, and ornamental and fruit trees. Verticillium wilt of alfalfa is one of the most serious diseases of alfalfa in the United States and Canada $(2,9,11,13,14,26)$. Yield losses due to infection with the pathogen may reach 50\% (29). It was first reported in North America in the Yakima Valley of Washington State by Graham et al (11) in 1976, and is believed to have been introduced from Europe by infested seed (6). Symptoms in infected plants include v-shaped chlorosis in leaflets, leaves that become pink in color after desiccation, and new leaves that desiccate soon after emergence from shoot tips. Infected plants of susceptible cultivars eventually wilt and die (23). The disease is primarily spread in the field during mechanical harvest of hay, but plants can also be infected as a result of feeding by insects carrying the pathogen (15,17-19). Control of the disease is effective only through the development and use of resistant varieties $(21,29)$. Busch et al. (4) have suggested that cultivars require at least $60 \%$ resistant plants for reasonable protection against V. albo-atrum. Several studies have indicated that resistance to Verticillium wilt increases both alfalfa yield $(20,36)$ and crop profitability $(31)$ when disease is present.

The influence of environmental factors on disease expression can make it difficult to accurately screen alfalfa for resistance to

Corresponding author: R. Larsen; E-mail address: rlarsen@tricity.wsu.edu

doi:10.1094/PHYTO-97-11-1519

This article is in the public domain and not copyrightable. It may be freely reprinted with customary crediting of the source. The American Phytopathological Society, 2007.
Verticillium wilt. Breeders interested in improving levels of resistance in alfalfa to $V$. albo-atrum can have confidence in their selection procedures only if there is a strong relationship between the resistance genotype of a plant and its disease reaction. The erroneous selection of a plant based on a favorable disease reaction due to environmental conditions that were not conducive to disease development, as opposed to being due to a desirable resistance genotype, can result in diminished gains due to selection.

Currently, commercial alfalfa varieties in the United States must be evaluated for resistance to $V$. albo-atrum using a standard test protocol for the resistance rating to be accepted by the National Alfalfa Variety Review Board. A positive and significant correlation has been observed between field resistance of alfalfa varieties and resistance ratings obtained using the standard test (13). The standard test is conducted by visually evaluating plants for disease symptoms and giving each plant a disease severity index (DSI) rating ranging from 1 to 5 , where $1=$ no to minimal chlorosis of lower leaves, and $5=$ dead plant (12). Plants scored as either a 1 or 2 (no chlorosis or necrosis of terminal leaves) are considered resistant. Populations are rated highly resistant (HR) if greater than $50 \%$ of the plants are resistant. Only populations with less than $6 \%$ resistant plants are considered susceptible (S).

A limitation of the DSI rating system employed by the standard test for evaluating alfalfa for resistance to Verticillium wilt is that it partitions plants into discrete classes based on evaluation of disease response. This may limit the ability of a breeder to select the most resistant plants among plants that are phenotypically indistinguishable. In addition, asymptomatic plants that were infected have been identified, and it has been suggested that these plants may serve as reservoirs of inoculum (7).

Differences have been noted between observed and claimed resistance ratings for several alfalfa cultivars (1). Oneida VR, 
considered to be HR, was rated resistant (R) based on results using the standard test protocol (12). Out of seven cultivars considered to have an $\mathrm{R}$ rating, five were classified as moderately resistant (MR), two of three cultivars considered to be MR were classified as having low resistance (LR), and a single cultivar considered to be LR was classified as being susceptible (S) (36). Similarly, it was observed under greenhouse conditions that the varieties Affinity $+\mathrm{Z}$ and Depend $+\mathrm{EV}$, although rated as HR, performed more like the resistant check variety Vertus (R) (35). Several alternatives to evaluating alfalfa for disease resistance based on visual examination have been explored. The ability to more quantitatively assess disease reaction could result in more accurate selection of highly resistant genotypes among plants having similar phenotypes. Initially it was demonstrated that the phenolic compounds medicarpin and sativan were accumulated in resistant alfalfa leaflets but not in susceptible leaflets $(21,27)$. Papadopoulos et al. (27) observed that resistant alfalfa seedlings accumulated higher levels of phenolic compounds after infection than susceptible seedlings. Newcombe et al (24) introduced the colonization ratio as a means to quantify resistance in alfalfa to $V$. albo-atrum. The colonization ratio, calculated as the number of secondary infection sites divided by number of primary infection sites, was determined microscopically and found to be inversely and significantly correlated with disease resistance. No observable levels of $V$. albo-atrum could be detected by microscopy in resistant stems 6 months after inoculations, while the fungus could be detected in both tolerant and susceptible plants (27).

The use of real-time polymerase chain reaction (PCR) (16) may provide a reliable method for quantitatively comparing the amount of $V$. albo-atrum present in resistant and susceptible alfalfa. Real-time PCR assays have been developed for quantifying Aphanomyces euteiches and Phytophthora medicaginis in alfalfa plants displaying various levels of disease severity $(33,34)$. Analysis of individual and bulked plant samples of resistant and susceptible alfalfa check populations has demonstrated a positive and significant correlation between pathogen DNA content in infected roots and disease severity for four different isolates of A. euteiches and a single isolate of $P$. medicaginis. Ranking of 15 different commercial alfalfa varieties based on real-time PCR results was positively and significantly correlated with ranking of the same varieties based on disease severity.

The objectives of this study were to develop a real-time PCR assay for quantifying $V$. albo-atrum in alfalfa and to apply the assay to examine the relationship between disease severity and pathogen DNA accumulation in different alfalfa cultivars.

\section{MATERIALS AND METHODS}

Plant materials. Three standard alfalfa check cultivars including Saranac (S), Vertus (MR), and Oneida (HR) were used in the experiments (12). In addition to the standard checks, three additional cultivars, Vernema (MR), Samauri (R) and Wrangler (LR) were also evaluated.

Experimental design and evaluation of disease severity. The experiment consisted of using a widely accepted standard test protocol (12) to evaluate 25 individual plants of each of the six cultivars for resistance to Verticillium wilt. Seeds of each cultivar were planted in a greenhouse in separate $25 \times 50 \mathrm{~cm}$ flats containing vermiculite. Plants were fertilized weekly with a commercial nutrient solution (Miracle Grow, Marysville, OH). Six weeks after sowing, 25 plants of each cultivar were inoculated with a conidial suspension of $V$. albo-atrum. Three isolates of the pathogen defined for the standard test (12) including Nyvall, N29 and W34 (kindly provided by M. Smith, Pioneer Hi-Bred Intl., Connell, WA) were used for inoculations. The isolates were maintained on potato dextrose agar at room temperature. An agar plug of each isolate was placed in a separate flask containing $250 \mathrm{ml}$ of Czapek's Dox broth (32), and the culture was grown at room temperature for 1 week with agitation. Cultures were filtered through two layers of cheesecloth. The conidial suspensions of each isolate were quantified with a hemacytometer and adjusted to a concentration of $1 \times 10^{6}$ condia $/ \mathrm{ml}$. An equal volume of conidial suspension of each isolate was aliquoted to make the inoculum. Plants were removed from flats and washed free of excess vermiculite. The roots were clipped to a length of approximately $8 \mathrm{~cm}$ and the stems were clipped to approximately $3 \mathrm{~cm}$. Plant roots were immersed completely for $20 \mathrm{~min}$ in a conidial suspension, which was agitated on a stir plate. Each plant was then immediately transplanted into a $10 \times 10 \mathrm{~cm}$ plastic pot containing commercial potting soil (Sun Gro Horticulture, Bellevue, WA). Sterile water was used as a control inoculation. Pots were randomized on benches after inoculations and maintained in the greenhouse at 20 to $24^{\circ} \mathrm{C}$ with a $14 \mathrm{~h}$ photoperiod. Plants were watered as needed to avoid drought stress, and fertilized every 2 weeks. Plants were evaluated visually for severity of foliar symptoms 4 weeks after inoculation and rated for DSI using an integer scale of 1 to 5 as follows: $1=$ no to minimal chlorosis of lower leaves; 2 = chlorosis of lower and middle leaves, but no chlorosis or necrosis of terminal leaves; 3 = well developed symptoms of chlorotic, necrotic, and twisted terminal leaflets on at least one, but not all main stems; $4=$ severe chlorosis, necrosis, and twisting of all leaflets on all main stems; and $5=$ dead plant (12). The experiment was repeated once.

Screening for RAPD markers and development of SCARs. Five different isolates of $V$. albo-atrum isolated from alfalfa including Lux, Nyvall, WI, N29, and W34 were used for initial screening of random amplified polymorphism DNA (RAPD) primers using the method described by Larsen et al. (22). Briefly, total DNA extracted from each of the five isolates was screened for RAPD markers (37) generated by random decamer primers (Operon Biotechnologies, Huntsville, AL). DNA was extracted from pathogens Aphanomyces euteiches, Fusarium oxysporum, F. solani, Mycospherella spp., Phoma sclerotioides, Phytophthora medicaginis, Pythium aphanidermatum, Pythium ultimum, Rhizoctonia solani, Verticillium albo-atrum, and V. dahliae using the protocol described by Vandemark et al. (35). Markers that were selectively amplified from all five isolates of $V$. albo-atrum but not from the other pathogens screened or healthy alfalfa controls were excised and purified from agarose gels using GeneCapsule (Geno Technology, Inc., St. Louis, MO). The purified DNA was cloned into the vector pCR4 Topo using the Topo TA cloning kit (Invitrogen, Carlsbad, CA) according to the manufacturer's instructions. Plasmid DNA was purified from Escherichia coli DH $10 \beta$ using alkaline lysis (30) and clones containing the PCR product were identified by digestion with EcoRI and visualized by agarose gel electrophoresis. The cloned DNA products were sequenced using the dideoxy-chain termination method. Extended primers were subsequently designed based on the $5^{\prime}$ and $3^{\prime}$ terminal sequences of the cloned products for conversion of the selected RAPD marker to a sequence-characterized amplified region (SCAR) marker (28).

Products from four of the decamer primers that produced RAPD markers were selected as candidates for SCAR primers. Primer OpB7 (5'-GGTGACGCAG-3') produced three amplification products of approximately 1,100, 1,500, and 2,600 bp, respectively, that were specific to each of the 5 isolates of $V$. alboatrum (Fig. 1A) but not the other pathogens or alfalfa DNA used as controls. Sequence data obtained from each of the three cloned amplicons were used to design the SCAR primers. After evaluation of PCR reactions using each of the three primer sets, the 1,513-bp SCAR marker that was common only to the $V$. alboatrum isolates was selected for use in all subsequent experiments and identified as SVert ${ }_{1513}$. This SCAR was selected because it produced the most robust single amplicon of the three primer sets evaluated and was efficient in a two step themocycling procedure. PCR utilizing SCAR primers SVert $_{1513}$ forward 5'-GGTGA- 
CGCAGCAGACGAGCGGGACCGTG-3' and SVert $_{1513}$ reverse 5'-GCACTTATAGTTGTTACCCCTGCGTCACC-3' were conducted using a two step thermocycling program that consisted of a single cycle of $5 \mathrm{~min}$ at $95^{\circ} \mathrm{C} ; 35$ cycles of $30 \mathrm{~s}$ at $94^{\circ} \mathrm{C}$ and $30 \mathrm{~s}$ at $72^{\circ} \mathrm{C}$.

Plant sampling and DNA extraction. Immediately after DSI ratings were conducted, the entire leaf and stem tissue of each plant was excised at the crown. DNA was extracted from the entire tissue sample using the FastDNA kit (Q-Biogene, Inc., Carlsbad, CA) according to the manufacturer's instructions. When plants were too large for processing in a single tube, additional tubes were used and the final DNA contents were then combined. DNA extracted from healthy alfalfa standard check cultivars Oneida VR, Saranac, and Vertus were used as controls. DNA extracts were quantified using a fluorometer (Turner Designs, Inc., Sunnyvale, CA) and adjusted to $10 \mathrm{ng} / \mu \mathrm{l}$ for use in real-time PCR.

Real-time PCR primer and probe design. The 1,513-bp DNA sequence corresponding to the SVert $_{1513}$ SCAR marker was analyzed using Primer Express software (Applied Biosystems, Foster City, CA) to identify nucleotide sequences for the primers and fluorochrome-labeled probe used in this study. The following primers and probe were synthesized (Applied Biosystems): for- ward primer vert853F 5'-CGAGTTCGCGGCAGGTA-3'; reverse primer vert927R 5'-GGCCACGCTAGCCTTCACTA-3', and the fluorchrome labeled probe: vert885T 5'-TTTCGACCTGCCGTGCGCG-3'. The probe was labeled at the $5^{\prime}$ terminus with the fluorochrome 6-carboflorescein (6-FAM) and at the $3^{\prime}$ terminus with the quencher tetra-methylcarboxyrhodamine (TAMRA). The primer/probe set vert853F-vert885T-vert927R amplifies a product $75 \mathrm{bp}$ in length.

Quantification of $\boldsymbol{V}$. albo-atrum in infected plants. DNA extracted from inoculated and control plants was amplified with primer/probe set vert853F-vert885T-vert927R. For each DNA sample, triplicate reactions were run in 50- $\mu$ l reactions containing $100 \mathrm{ng}$ of DNA, $25 \mu \mathrm{l}$ of $2 \times$ TaqMan Universal PCR master mix (Applied Biosystems), $900 \mathrm{nM}$ of each forward and reverse primer, and $250 \mathrm{nM}$ of probe. Amplifications and detection of fluorescence were conducted using the ABI Prism 7000 Sequence Detection System (Applied Biosystems). The thermalcycling profile consisted of an initial cycle of $2 \mathrm{~min}$ at $50^{\circ} \mathrm{C}$ followed by a single cycle of $10 \mathrm{~min}$ at $95^{\circ} \mathrm{C}$, then 40 cycles of $15 \mathrm{~s}$ at $95^{\circ} \mathrm{C}$ and $1 \mathrm{~min}$ at $60^{\circ} \mathrm{C}$.

Standard curves were constructed for each of three isolates (Nyvall, N29, and W34) of V. albo-atrum using triplicate realtime reactions for different quantities of DNA $(0.001,0.01,0.1$,
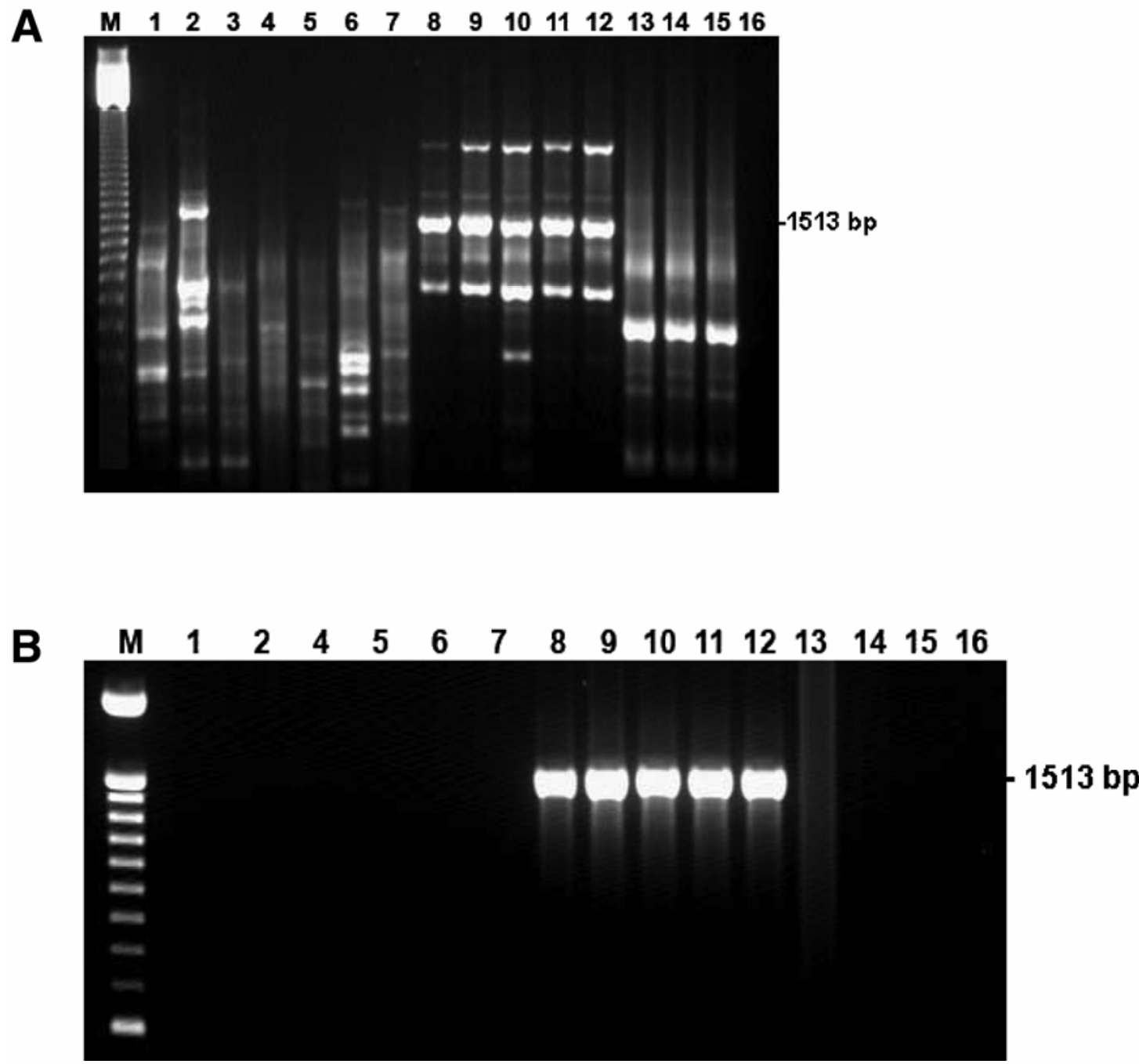

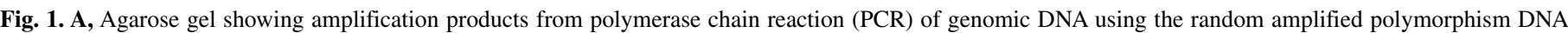

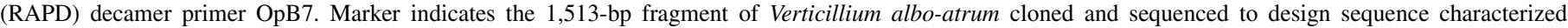

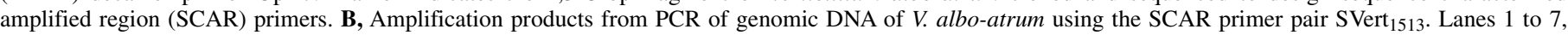

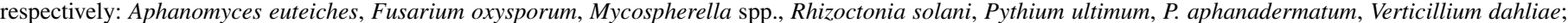

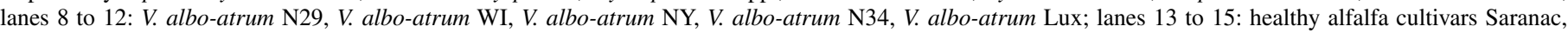
Oneida VR, Vertus; and lane 16: water control. 
$1.0,10,25$, and $50 \mathrm{ng}$ ) plotted against cycle threshold $(\mathrm{Ct})$ values. The specificity of the assay was evaluated by testing against $50 \mathrm{ng}$ of DNA from the nontarget pathogen and host genomes listed in Table 1. Every set of reactions also included a water control to verify the lack of contamination of reagents by template DNA.

Data analysis. Analysis of variance (ANOVA) and pairwise $t$ tests were performed using JMP Statistical Discovery Software (SAS Institute, Cary, NC) on DSI scores and real-time PCR data to determine if significant differences could be detected among populations within the six different. cultivars For each experiment, the Spearman rank correlation (25) between the DSI score and amount of pathogen DNA was calculated using the mean of three replicate quantitative PCR reactions for each plant sample.

\section{RESULTS}

SCAR detection and analysis. The single SCAR product $\left(\right.$ SVert $\left._{1513}\right)$ developed from the 1,513-bp amplicon produced by RAPD primer OpB7 (Fig. 1A) was cloned and both strands were completely sequenced. The sequence represents a fragment and was submitted to GenBank (accession no. DQ333342). No significant homology could be detected with any fungal or plant DNA sequences present in the GenBank database.

In PCR the SVert $_{1513}$ primers unambiguously identified the five isolates of $V$. albo-atrum but did not react with DNA from the other pathogens or healthy alfalfa used as controls (Fig. 1B). In separate experiments to demonstrate specificity of the primer/ probe set vert853F-vert885T-vert927R for $V$. albo-atrum, DNA was extracted and amplified as described above from 9 additional isolates of V. albo-atrum obtained from alfalfa samples collected in Minnesota, Washington State, and Wisconsin, and eight additional isolates of $V$. dahliae obtained from hosts listed in Table 1. Amplicons of the expected size were obtained for all $V$. alboatrum isolates using the SCAR primers and none were produced from any of the $V$. dahliae isolates (data not shown).

To evaluate the application for detection of $V$. albo-atrum in plant samples obtained from the field, the $\mathrm{SVert}_{1513}$ primers in PCR successfully identified the pathogen in 24 dried alfalfa stem and leaf samples collected in Wisconsin, but not from healthy controls (data not shown). The identity of the pathogen was previously verified on the freshly collected samples by micoscopic examination where conidiophores typical of $V$. albo-atrum were observed emerging from petioles and leaflets of these tissues.

Specificity and precision of the real-time assay for $V$. alboatrum. Real-time PCR assays using primer/probe set vert853Fvert885T-vert927R could detect DNA of $V$. albo-atrum in linear assays within a range of DNA quantities from 0.001 to $50 \mathrm{ng}$. Very similar results were obtained for all 14 isolates of $V$. alboatrum for the standard curve equations, with correlations between the $\log _{10}$ of the initial DNA quantities and the $\mathrm{C}_{\mathrm{T}}$ values ranging between 0.994 and 0.999 for all 14 isolates of $V$. albo-atrum, suggesting that the assay precisely quantifies target DNA. The real-time assay did not amplify DNA from any other pathogens evaluated or from six different healthy alfalfa controls (Table 1), indicating that the assay was highly specific for $V$. albo-atrum. Three replicate real-time reactions were performed for each plant,

TABLE 1. Specificity of primer/probe set vert853F-vert885T-vert927R for detection of Verticillium albo-atrum DNA $^{\mathrm{x}}$

\begin{tabular}{|c|c|c|c|c|}
\hline Pathogen/host DNA & Host source & Geographic origin & SCAR reaction $^{\mathrm{y}}$ & Real-time PCR amplification ${ }^{z}$ \\
\hline Verticillium albo-atrum ARI & Alfalfa & Wisconsin & + & + \\
\hline V. albo-atrum ARI 86B-1 & Alfalfa & Wisconsin & + & + \\
\hline V. albo-atrum ARI 86B-2 & Alfalfa & Wisconsin & + & + \\
\hline V. albo-atrum Freitag 1098 & Alfalfa & Wisconsin & + & + \\
\hline V. albo-atrum Freitag 799 & Alfalfa & Wisconsin & + & + \\
\hline V. albo-atrum Loken 199 & Alfalfa & Wisconsin & + & + \\
\hline V. albo-atrum Loken 298 & Alfalfa & Wisconsin & + & + \\
\hline V. albo-atrum Lux & Alfalfa & Washington & + & + \\
\hline V. albo-atrum Nyvall & Alfalfa & Minnesota & + & + \\
\hline V. albo-atrum N29 & Alfalfa & Washington & + & + \\
\hline V. albo-atrum Sevcik-1 & Alfalfa & Wisconsin & + & + \\
\hline V. albo-atrum Sevcik-2 & Alfalfa & Wisconsin & + & + \\
\hline V. albo-atrum $\mathrm{W} 34$ & Alfalfa & Washington & + & + \\
\hline V. albo-atrum WI & Alfalfa & Wisconsin & + & + \\
\hline Verticillium dahliae & Alfalfa & Wisconsin & - & ND \\
\hline V. dahliae & Apricot & Oregon & - & ND \\
\hline V. dahliae & Ash & Oregon & - & ND \\
\hline V. dahliae & Mint & Washington & - & ND \\
\hline V. dahliae 06-R1 & Potato & Oregon & - & ND \\
\hline V. dahliae N11 & Potato & Oregon & - & ND \\
\hline V. dahliae-WA & Potato & Washington & - & ND \\
\hline V. dahliae & Spinach & Washington & - & ND \\
\hline V. dahliae & Watermelon & Oregon & - & ND \\
\hline Aphanomyces euteiches & Alfalfa & Washington & - & ND \\
\hline Fusarium oxysporum & Pea & Washington & - & ND \\
\hline F. solani & Pea & Washington & - & ND \\
\hline Mycospharella spp. & Pea & Washington & - & ND \\
\hline Phoma sclerotioides & Alfalfa & Wyoming & - & ND \\
\hline Phytophthora medicaginis & Alfalfa & Washington & - & ND \\
\hline Pythium aphanidermatum & Common bean & Washington & - & ND \\
\hline Pythium ultimum & Pea & Washington & - & ND \\
\hline Rhizoctonia solani & Pea & Washington & - & ND \\
\hline Saranac & Alfalfa cultivar & NA & - & ND \\
\hline Vernema & Alfalfa cultivar & NA & - & ND \\
\hline Oneida HR & Alfalfa cultivar & NA & - & ND \\
\hline Samurai & Alfalfa cultivar & NA & - & ND \\
\hline Wrangler & Alfalfa cultivar & NA & - & ND \\
\hline Vertus & Alfalfa cultivar & NA & - & ND \\
\hline
\end{tabular}

${ }^{\mathrm{x}}$ Initial amplifications were performed using $50 \mathrm{ng}$ of genomic DNA as template.

y Sequence characterized amplified region. Marker present $=+$; marker absent $=-$.

z Amplification by real-time polymerase chain reaction $(\mathrm{PCR})$ : detected $=+$; not detected $=$ ND. 
and PCR replicate-plant interactions were not significant for either experiment $1(P>0.98)$ or experiment $2(P>0.97)$. These results demonstrate the high level of reproducibility that was observed among replicated real-time reactions performed on any given plant sample.

Relationships between disease severity index ratings and quantity of DNA detected in individual plants. Analysis of variance indicates that significant differences were detected between cultivars for the quantity of pathogen DNA detected in plants and also for DSI scores (Table 2). No significant differences in pathogen DNA quantity or DSI were observed for experiments or for cultivar-experiment interactions (Table 2).

A comparison of means indicates that in both experiments the check cultivar Oneida VR (HR) had a significantly lower DSI than all other cultivars, except for Vertus (R) in Experiment 2. In both experiments, the check cultivar Vertus $(\mathrm{R})$ had a significantly lower DSI than Wrangler (LR) and Saranac (S). No significant differences in DSI were observed in either experiment between Vernema, Samauri, and Wrangler, although these three cultivars are all in different resistance classes (Table 3).

No significant differences in pathogen DNA content were observed between the check cultivars Oneida VR (HR) and Vertus (R) (Table 3). However, in both experiments Oneida VR had significantly less pathogen DNA than all other cultivars besides Vertus. Differences in pathogen DNA quantity were not significant in either experiment between Samauri (R) and Wrangler (LR), nor were significant differences in pathogen DNA quantity observed between Vernema (MR) and the check cultivar Saranac (S). In both experiments, the Spearman rank correlation between

TABLE 2. Analysis of variance for the quantity of Verticillium albo-atrum DNA detected in alfalfa plants and disease severity index (DSI) ratings of inoculated plants

\begin{tabular}{|c|c|c|c|c|c|}
\hline \multirow[b]{2}{*}{ Source $\mathrm{x}$} & \multicolumn{3}{|c|}{ DNA $^{y}$} & \multicolumn{2}{|c|}{$\mathrm{DSI}^{\mathrm{z}}$} \\
\hline & df & $F$ value & $P>F$ & $F$ value & $P>F$ \\
\hline Cultivar & 5 & 2.44 & 0.03 & 11.44 & $<0.0001$ \\
\hline Experiment & 1 & 1.14 & 0.29 & 0.75 & 0.40 \\
\hline Population $\times$ experiment & 5 & 0.44 & 0.82 & 0.75 & 0.59 \\
\hline
\end{tabular}

x Six alfalfa populations were examined: Oneida VR, Vertus, Saranac, Samauri, Vernema, and Wrangler. Each of two experiments consisted of 25 plants of each cultivar.

y The amount of $V$. albo-atrum DNA present in $100 \mathrm{ng}$ of total DNA extracted from infected plants was quantified using the primer/probe set vert853Fvert885T-vert927R. Three real-time polymerase chain reaction (PCR) assays were performed for each plant.

${ }^{\mathrm{z}}$ Plants were evaluated for resistance to Verticillium wilt using a scale from 1 to 5 as follows: 1 = no to minimal chlorosis of lower leaves; $2=$ chlorosis of lower and middle leaves, but no chlorosis or necrosis of terminal leaves; $3=$ well developed symptoms of chlorotic, necrotic and twisted terminal leaflets on at least one, but not all main stems; $4=$ severe chlorosis, necrosis, and twisting of all leaflets on all main stems; and $5=$ dead plant. the DSI score of a plant and the quantity of $V$. albo-atrum DNA detected in a plant was positive and significant (Table 3).

\section{DISCUSSION}

Verticillium wilt is a severe soilborne disease of alfalfa in North America $(2,13,14)$. We developed SCARs specific to the strain of V. albo-atum isolated from 13 alfalfa fields over a 22-year period in Minnesota, Washington, and Wisconsin. Although it is possible that the SCAR may not be specific for all strains of the pathogen, this does not appear to be likely for those isolated from alfalfa. Corell et al. (8) found that 15 strains of V. albo-atrum collected from several countries around the world were in the same vegetative compatibility group suggesting that strains from alfalfa may represent a genetically homogeneous clonal population. In another study, Carder and Barbara (5) developed DNA probes to detect polymorphisms between $V$. albo-atrum and V. dahliae, and their results indicated that all isolates of $V$. albo-atrum from alfalfa were identical. As a result of these reports, we did not conduct exhaustive experiments to test isolates of the pathogen, independent of its host range, from around the United States. In addition, a defined set of isolates is typically used in the standard test (12) to evaluate alfalfa cultivars for resistance to $V$. alboatrum. In this case, detection of all isolates is not required. Beyond its usefulness in general detection of the pathogen in alfalfa, the SCAR provided sequence information from which to generate a primer/probe set for use in a real-time PCR assay for quantifying the amount of $V$. albo-atrum DNA present in infected plants. The specificity of the real-time assay to V. albo-atrum was demonstrated by testing DNA extracted from pure cultures of several other soilborne pathogens of alfalfa and from uninoculated plants of the three standard check cultivars Oneida VR, Vertus, and Saranac (Table 1). Correlations between the $\log _{10}$ of initial DNA quantities and $\mathrm{C}_{\mathrm{T}}$ values exceeded 0.99 for all three tested isolates of $V$. albo-atrum, demonstrating the precision of the assay within a range of genomic DNA from $1 \mathrm{pg}$ to $50 \mathrm{ng}$.

In a repeated experiment, plants of six alfalfa cultivars having different levels of resistance to Verticillium wilt were inoculated with the pathogen and visually evaluated for DSI according to widely accepted standard conditions (12). DNA was extracted from the entire stem and leaf tissues of each plant and the amount of V. albo-atrum DNA present in equal quantities of total DNA from each plant was estimated by real-time PCR. The lack of significant effects observed due to experiments or cultivar-experiment interactions for either DSI or pathogen DNA content (Table 2) suggests that similar environmental conditions were maintained across both experiments. Significant effects attributed to cultivars for both pathogen DNA content and DSI likely reflect differences between cultivars in resistance to Verticillium wilt. Rankings for DSI of the three standard check cultivars were generally consistent with expected results based on known levels

TABLE 3. Comparison of means for quantity (pg) of Verticillium albo-atrum DNA ${ }^{\mathrm{w}}$ and disease severity index (DSI) ${ }^{\mathrm{x}}$ ratings among alfalfa cultivars

\begin{tabular}{|c|c|c|c|c|c|}
\hline \multirow[b]{2}{*}{ Cultivar } & \multirow[b]{2}{*}{ Resistance ratingy } & \multicolumn{2}{|c|}{ Experiment 1} & \multicolumn{2}{|c|}{ Experiment 2} \\
\hline & & DNA & DSI & DNA & DSI \\
\hline Saranac & $\mathrm{S}$ & $46.1 \mathrm{ab}$ & $3.32 \mathrm{a}$ & $49.4 \mathrm{a}$ & $3.44 \mathrm{a}$ \\
\hline Vernema & MR & $70.1 \mathrm{a}$ & $3.04 \mathrm{a}$ & $51.6 \mathrm{a}$ & $2.40 \mathrm{bc}$ \\
\hline Samauri & $\mathrm{R}$ & $42.7 \mathrm{~b}$ & $2.68 \mathrm{ab}$ & $45.9 \mathrm{a}$ & $2.72 \mathrm{~b}$ \\
\hline Wrangler & LR & $39.1 \mathrm{~b}$ & $2.76 \mathrm{a}$ & $38.3 \mathrm{a}$ & $2.64 \mathrm{~b}$ \\
\hline Vertus & $\mathrm{R}$ & $33.0 \mathrm{bc}$ & $2.04 \mathrm{~b}$ & $4.2 \mathrm{~b}$ & $1.88 \mathrm{~cd}$ \\
\hline Oneida VR & HR & $11.2 \mathrm{c}$ & $1.20 \mathrm{c}$ & $1.9 \mathrm{~b}$ & $1.27 \mathrm{~d}$ \\
\hline$\rho(\text { Prob }>|\rho|)^{z}$ & & $0.52(<0.0001)$ & & $0.53(<0.0001)$ & \\
\hline
\end{tabular}

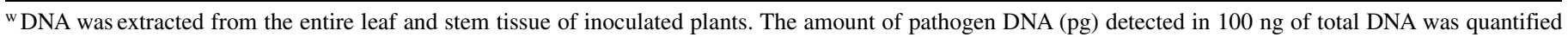
using primer probe set vert853F-vert885T-vert927R. Each plant was tested with three replicate real-time polymerase chain reaction (PCR) assays.

x Plants were evaluated for resistance to Verticillium wilt using a DSI rating scale from 1 (healthy) to 5 (dead).

${ }^{y}$ Cultivar resistance rating: $\mathrm{S}=$ susceptible; $\mathrm{LR}=$ low resistance; $\mathrm{MR}=$ moderately resistant; $\mathrm{R}=$ resistant; $\mathrm{HR}=$ highly resistant.

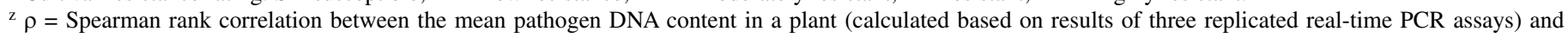
DSI. $N=150$ plants/experiment. 
of disease resistance (Table 3). However, in both experiments, the mean DSI of Vernema (MR) was not significantly different than Wrangler (LR) (Table 3). This suggests that in these experiments Vernema expressed low resistance to Verticillium wilt as opposed to its reported rating of moderate resistance (1). In previous examinations using different alfalfa cultivars and different isolates of V. albo-atrum, several cultivars have been observed to be less resistant to Verticillium wilt than expected $(2,35,36)$. Inconsistent disease reaction of specific cultivars may be due to differences across tests in environmental conditions, pathogen isolates, genotype-environment interactions, and the inherent genetic heterogeneity of synthetic alfalfa populations (3).

Previously there have been no techniques that could be used to accurately quantify $V$. albo-atrum in infected alfalfa plants. The fungus does not produce easily visible spores on diseased plants or sclerotia that can be rapidly and accurately quantified. Although Newcombe et al. (24) developed the colonization ratio to compare alfalfa cultivars for resistance to V. albo-atrum, this ratio was determined based on microscopic analysis of stained stem cross-sections, a method that did not appear to be amenable to sampling large numbers of stems per population, as only a single plant was examined for each population, with five stems being examined for each plant. Papadopoulus et al. (27) estimated the average stem colonization (ACOL) for several alfalfa cultivars. However, ACOL was not calculated based on a continuous classification system, but rather using a binary scoring system in which stems were examined microscopically for the presence of $V$. alboatrum mycelia, and stems in which the fungus was observed received a colonization score $(\mathrm{COL})=2$, while stems in which no fungus was observed were rated using $\mathrm{COL}=1$. ACOL values for cultivars were compared with disease index ratings using a scale of 0 (no foliar symptoms) to 5 (dead plant), and the correlation between the two rating systems were positive and significant. We similarly observed in repeated experiments a positive and significant correlation between DSI and the quantity of $V$. albo-atrum DNA detected in stems and foliage of infected plants (Table 3). The previous observations of Papadopoulus et al. (27), which indicated that disease severity was correlated with the incidence of fungal colonization of stem tissue, suggests that the positive and significant correlation between disease severity and pathogen DNA content reflects a greater abundance of pathogen biomass in tissue of susceptible alfalfa cultivars. Previous use of real-time PCR assays to quantify A. euteiches and P. medicaginis DNA in resistant and susceptible alfalfa has also demonstrated positive and significant correlations between disease severity and pathogen DNA content in infected roots (34). These results indicate that real-time PCR assays have repeatedly demonstrated that resistance in alfalfa to several soilborne diseases is characterized by the presence of lower amounts of pathogen biomass in resistant plants.

Pathogen DNA was detected in most asymptomatic plants (DSI = 1), which indicates that it cannot be reliably determined if a plant is infected with $V$. albo-atrum based solely on the presence of symptoms. These results are similar to those previously observed based on the microscopic examination of alfalfa stems for the presence of mycelium of $V$. albo-atrum, in which asymptomatic plants were identified that were colonized by the fungus (27). Christie et al. (7) proposed that there were two types of resistance in alfalfa to V. albo-atrum, one that results in the complete inhibition of colonization of the host, and another type characterized by a tolerance of the host to limited pathogen colonization. Infected plants that exhibit no symptoms of disease may serve as sources of inoculum for subsequent infections, and it is possible that in the future these plants could exhibit symptoms in the presence of environmental factors that promote disease expression, such as excess soil moisture (10) and cool temperatures (13). In this study, asymptomatic alfalfa plants were also identified in which no pathogen could be detected and it is likely that these plants are highly resistant to Verticillium wilt. Hence, the use of quantitative PCR can be used to a significant advantage by breeders in identifying true resistant sources to V. albo-atrum. Although plants are not typically re-evaluated for disease resistance, the ability to clonally propagate alfalfa may make it possible to conduct additional evaluations on promising materials for resistance to the pathogen.

\section{LITERATURE CITED}

1. Alfalfa Council. 2005. Fall dormancy and pest resistance ratings for alfalfa varieties. Alfalfa Council, Kansas City, MO.

2. Atkinson, T. G. 1981. Verticillium wilt of alfalfa: Challenge and opportunity. Can. J. Plant Pathol. 3:266-272.

3. Busbice, T. H., Hill, R. R., and Carnahan, H. L. 1972. Genetics and breeding procedures. Pages 283-314 in: Alfalfa Science and Technology. C. H. Hanson, ed. American Society of Agronomy, Madison, WI.

4. Busch, L. V., Christie, B. R., Smith, E. A., and Boland, G.. 1985. Testing alfalfa cultivars for resistance to an alfalfa strain of Verticillium alboatrum. Can. J. Plant Pathol. 7:203-205.

5. Carder, J. H., and Barbara, D. J. 1991. Molecular variation and restriction fragment length polymorphisms (RFLPs) within and between six species of Verticillium. Mycol. Res. 95:935-942.

6. Christen, A. A. 1982. Demonstration of Verticillium albo-atrum within alfalfa seed. Phytopathology 72:412-414.

7. Christie, B. R., Papadopoulos, Y. A., and Buschet, L. V. 1985. Genetics and breeding for resistance to Verticillium wilt in alfalfa. Can. J. Plant Pathol. 7:206-210.

8. Correll, J. C., Gordon, T. R., and McCain, A. H. 1988. Vegetative compatibility and pathogenicity of Verticillium albo-atrum. Phytopathology 78:1017-1021.

9. Gordon, T. R., Correll, J. C., Gilchrist, D. G., and Martensen, A. N. 1989. Verticillium wilt of alfalfa in California. Plant Dis. 73:18-20.

10. Gossen, B. D., and Jefferson, P. G. 2004. A novel source of resistance to Verticillium wilt in alfalfa. Can. J. Plant Sci. 84:401-404.

11. Graham, J. H., Peaden, R. N., and Evans, D. W. 1977. Verticillium wilt of alfalfa found in the United States. Plant Dis. Rep. 61:337-340.

12. Grau, C. R. 1991. Standard Test: Verticillium wilt resistance. North American Alfalfa Improvement Conference. Online publication. http://www.naaic.org.

13. Grau, C. R., Delwiche, P. A., Norgren, R. L., O’Connell, T. E., and Maxwell, D. P. 1981. Verticillium wilt of alfalfa in Wisconsin. Plant Dis. 65:843-844.

14. Gray, F. A., and Roth, D. A. 1982. Verticillium wilt of alfalfa in Wyoming. Plant Dis. 66:1080.

15. Harper, A. M., and Huang, H. C. 1984. Contamination of insects by the plant pathogen Verticillium albo-atrum in an alfalfa field. Environ. Entomol. 13:117-120.

16. Heid, C. A., Stevens, J., Livak, K. J., and Williams, P. M. 1996. Real time quantitative PCR. Genome Res. 6:986-994.

17. Huang, H. C., Hanna, M. R., and Kokko, E. G. 1985. Mechanisms of seed contamination by Verticillium albo-atrum in alfalfa. Phytopathology 75:482-488.

18. Huang, H. C., Richards, K. W., and Kokko, E. G. 1986. Role of the leafcutter bee in dissemination of Verticillium albo-atrum in alfalfa. Phytopathology 76:75-79.

19. Huang, H. C., Harper, A. M., Kokko, E. G., and Howard, R. J. 1983. Aphid transmission of Verticillium albo-atrum to alfalfa. Can. J. Plant Pathol. 5:141-147.

20. Huang, H. C., Acharya, S. N., Hanna, M. R., Kozub, G. C., and Smith, E. G. 1994. Effect of Verticillium wilt on forage yield of alfalfa in southern Alberta. Plant Dis. 78:1181-1184.

21. Kratka, J., and Kudela, V. 1981. Biochemical changes in alfalfa plants inoculated with Verticillium albo-atrum. Phytopathol. Z. 100:289-299.

22. Larsen, R. C., Hollingsworth, C. R., Vandemark, G. J., Gritsenko, M. A., and Gray, F. A. 2002. A rapid method using PCR-based SCAR markers for the detection and identification of Phoma sclerotioides: The cause of brown root rot disease of alfalfa. Plant Dis. 86:928-932.

23. Leath, K. T., and Pennypacker, B. W. 1990. In: Compendium of Alfalfa Diseases. D. L. Stuteville and D. C. Erwin, eds. American Phytopathological Society, St. Paul, MN.

24. Newcombe, A. G, Papadopoulos, Y. A., Robb, J., and Christie, B. R. 1989. The colonization ratio: A measure of pathogen invasiveness and host resistance in Verticillium wilt of alfalfa. Can. J. Bot. 67:365-370.

25. Ostle, B. 1954. Correlation methods. Pages 174-201 in: Statistics in Research. Iowa State College Press, Ames, IA.

26. Page, M. S., Gray, F. A., Legg, D. E., and Kearl, W. G. 1992. Economic impact and management of Verticillium wilt on irrigated alfalfa hay 
production in Wyoming. Plant Dis. 76:504-508.

27. Papadopoulos, Y. A., Christie, B. R., Boland, G. J., and Busch, L. V. 1990. The use of histochemical analysis and stem colonization for distinguishing reactions of alfalfa to Verticillium wilt. Can. J. Bot. 69:12751283.

28. Paran, I., and Michelmore, R. W. 1993. Development of reliable PCRbased markers linked to downy mildew resistance genes in lettuce. Theor. Appl. Genet. 85:985-993.

29. Peaden, R. N., Gilbert, R. G., and Christen, A. A. 1985. Control of Verticillium albo-atrum on alfalfa. Can. J. Plant Pathol. 7:211-214.

30. Sambrook, J., Fritsch, E. F., and Maniatis, T. 1989. Molecular Cloning: A Laboratory Manual. 2nd ed. Cold Spring Harbor Laboratory, Cold Spring Harbor, NY.

31. Smith, E. G., Acharya, S. N., and Huang, H. C. 1995. Economics of growing Verticillium wilt resistant and adapted alfalfa cultivars in Western Canada. Agron. J. 87:1206-1210.
32. Tuite, J. 1969. Plant Pathological Methods. Burgess Publishing Co. Minneapolis, MN.

33. Vandemark, G. J., and Barker, B. M. 2003. Quantifying Phytophthora medicaginis in susceptible and resistant alfalfa with a real-time PCR assay. J. Phytopathol. 151:577-583.

34. Vandemark, G. J., Barker, B. M., and Gritsenko, M. A. 2001. Quantifying Aphanomyces euteiches in alfalfa with a fluorescent polymerase chain reaction assay. Phytopathology 92:265-272.

35. Vandemark, G. J., Larsen, R. C., and Hughes, T. J. 2006. Heritability of resistance to Verticillium wilt in alfalfa. Plant Dis. 90:314-318.

36. Viands, D. R., Lowe, C. C., Bergstrom, G. C., Vaughn, D. L., and Hansen, J. L. 1992. Association of level of resistance to Verticillium wilt with alfalfa forage yield and stand. J. Prod. Agric. 5:504-509.

37. Williams, J. G. K., Kubelik, A. R., Livak, K. J., Rafalski, J. A., and Tingley, S. V. 1990. DNA polymorphisms amplified by arbitrary primers are useful as genetic markers. Nucleic Acids Res. 18:6531-6535. 